\title{
PERBANDINGAN NILAI SIFAT-SIFAT CAMPURAN LAPISAN ASPAL BETON (LATASTON) HRS-BASE GRADASI SENJANG MENGGUNAKAN AGREGAT PADA $Q U A R R Y$ MARTADAH DAN QUARRY AWANG BANGKAL
}

\author{
Daniel Ajie Saputra ${ }^{1}$, Akhmad Gazali ${ }^{2}$, Robiatul Adawiyah ${ }^{2}$ \\ ${ }^{1}$ Mahasiswa Program Studi Teknik Sipil Fakultas Teknik Universitas Islam Kalimantan \\ Muhammad Arsyad Al Banjari Banjarmasin \\ ${ }^{2}$ Dosen Program Studi Teknik Sipil Fakultas Teknik Universitas Islam Kalimantan Muhammad \\ Arsyad Al Banjari Banjarmasin \\ E-mail: danielajiesaputr@gmail.com/ HP. 081250702959
}

\begin{abstract}
ABSTRAK
Dalam pengujian ini bertujuan untuk mengetahui hasil sifat-sifat yang dimiliki campuran beraspal HRS-Base gradasi senjang serta perbandingan berdasarkan agregat yang digunakan. Agregat yang digunakan dalam pengujian ini adalah agregat yang berada pada quarry Martadah dengan quarry Awang Bangkal. Perancangan campuran ini menggunakan metode Ideal Gradasi yang berdasar pada nilai tengah batas-batas spesifikasi umum gradasi agregat campuran HRS-Base.

Pada perancangan yang telah dilakukan dengan metode Ideal Gradasi didapatkan proporsi campuran yaitu CA $55 \%$, FA $39,5 \%$ dan FF 5,5\%. Dari hasil pengujian didapat sifat-sifat campuran dengan agregat quarry Martadah yaitu, VIM 4,89\%, VMA 17,56\%, VFB 72,32\%, Flow 4,00 mm, Marshall Quotient 271,86 kg/mm, Stabilitas Marshall 1083,41 kg, VIM PRD 4,10\%, Stabilitas Sisa 90,16\% dan Kadar Aspal Optimum 6,55\% sedangkan dengan agregat quarry Awang Bangkal yaitu, VIM 5,51\%, VMA 17,29\%, VFB 68,20\%, Flow 3,49 mm, Marshall Quotient $250,30 \mathrm{~kg} / \mathrm{mm}$, Stabilitas Marshall 865,30 kg, VIM PRD 4,60\%, Stabilitas Sisa 90,49\% dan Kadar Aspal Optimum 6,40\%.

Dari hasil/ nilai pada pengujian Marshall pada kedua agregat maka dapat kita simpulkan bahwa secara garis besar nilai sifat-sifat campuran pada Lataston quarry Martadah lebih besar dibandingkan dengan quarry Awang Bangkal.
\end{abstract}

Kata Kunci: Sifat Campuran; Ideal Spesifikasi; Quarry Martadah; Quarry Awang Bangkal.

\section{ABSTRACT}

In this test aims to determine the results of the properties possessed by HRS-Base asphalt pavement mixtures and aggregate based comparisons used. The aggregate used in this test is Martadah quarry with Awang Bangkal quarry. The design of this mixture uses the Ideal Gradation method based on the middle value of the general specification limits of the HRS-Base aggregate mixture gradation.

In the design that has been carried out with the Ideal Gradation method, the mixture proportion is CA 55\%, FA 39.5\% and FF 5.5\%. From the test results obtained the properties of the mixture with Martadah quarry aggregate, namely VIM 4,89\%,VMA 17,56\%, VFB 72,32\%, Flow 4,00 mm, Marshall Quotient 271,86 kg/mm, Marshall Stability 1083,41 kg, VIM PRD 4,10\%, Residual Stability 90,16\% and Optimum Asphalt Content 6,55\% while with Awang Bangkal quarry aggregate namely, VIM 5.51\%, VMA 17.29\%, VFB 68.20\%, Flow 3.49 mm, Marshall Quotient $250.30 \mathrm{~kg} / \mathrm{mm}$, Marshall Stability $865.30 \mathrm{~kg}$, VIM PRD 4.60\%, Residual Stability 90.49\% and Optimum Asphalt Content 6.40\%.

From the results / values in the Marshall test on both aggregates, we can conclude that the outline of the values of the mixed properties in Lataston quarry Martadah is greater than the quarry Awang Bangkal.

Keywords: Mixed nature; Ideal Specifications; Martadah Quarry; Awang Bangkal Quarry. 


\section{PENDAHULUAN \\ Latar Belakang}

Pada pelaksanaan pekerjaan konstruksi jalan raya, komponen material terdiri dari bahanbahan di atas permukaan tanah yang harus tahan terhadap beban lalu lintas kendaraan serta terhadap pengaruh cuaca. Untuk menunjang hal tersebut sangatlah diperlukan peninjauan pada produksi campuran aspal panas yang dilakukan dengan campuran rancangan (Design Mix Formula) untuk mendapatkan komposisi yang sesuai.

Campuran yang dibuat untuk lapisan aspal panas adalah campuran antara agregat dan aspal dalam keadaan panas, dengan atau tanpa bahan tambahan yang telah sesuai dengan proporsi yang ditentukan. Perancangan proporsi dapat dilakukan dengan berbagai metode, yaitu metode Trial Error, metode Grafis dan Ideal Gradasi. Ideal Gradasi merupakan metode perancangan berdasar pada nilai dengan ketentuan spesifikasi.

Pada pelaksanaan penelitian dan pengujian akan dapat diketahui perbandingan parameter pada bahan agregat dan parameter bahan aspal. Bahan agregat utama yang digunakan adalah batu pecah dari Gunung Martadah dan Awang Bangkal yang telah dikenal materialnya memiliki kekuatan dan hasil parameter yang cukup bagus. Parameter pada bahan agregat dapat diketahui dalam penelitian seperti analisa saringan, penyerapan agregat, berat jenis, gradasi dan abrasi. Sedangkan pada bahan aspal dapat diketahui dalam penelitian seperti berat jenis, penyerapan agregat, daktilitas, penetrasi dan titik lembek.

\section{Rumusan Masalah}

Rumusan masalah peninjauan yang dilakukan pada campuran aspal panas dan campuran rancangan dalam Skripsi ini adalah :

1. Bagaimanakah hasil/ nilai parameter sifat-sifat campuran HRS-Base gradasi senjang dengan agregat kasar quarry Martadah yang berdasar pada Ideal Spesification?

2. Bagaimanakah hasil/ nilai parameter sifat-sifat campuran HRS-Base gradasi senjang dengan agregat kasar quarry Awang Bangkal yang berdasar pada Ideal Spesification?

3. Bagaimanakah hasil/ nilai perbandingan parameter sifat-sifat campuran Lataston HRS-Base gradasi senjang antara quarry Martadah dengan quarry Awang Bangkal sesuai Ideal Specification?

\section{Tujuan Penelitian}

Tujuan dari peninjauan campuran aspal panas dalam Skripsi ini adalah untuk :

1. Mengetahui hasil sifat-sifat campuran yang dimiliki Lataston HRS-Base Gradasi Senjang dengan menggunakan agregat kasar quarry Martadah.

2. Mengetahui hasil sifat-sifat campuran yang dimiliki Lataston HRS-Base Senjang dengan menggunakan agregat kasar quarry Awang Bangkal.

3. Mendapatkan hasil perbandingan hasil/nilai sifat-sifat campuran Lataston HRS-Base gradasi senjang antar quarry Martadah dengan Awang Bangkal.

\section{Manfaat Penulisan}

Manfaat yang didapat dalam peninjauan campuran aspal panas dalam campuran rancangan (Design Mix Formula) dalam Skripsi ini adalah untuk mengetahui informasi sifat-sifat campuran antar agregat pada campuran aspal HRS-Base.

\section{Batasan Masalah}

Agar penelitian ini terfokus pada rumusan masalah maka perlu diberikan batasan-batasan sebagai berikut :

1. Pengujian sifat-sifat campuran Lataston berdasarkan sampel yang telah diambil dengan test Marshall berdasarkan ideal specification.

2. Pengujian dilakukan pada campuran aspal Hot Rolled Sheet Base (HRS-Base) gradasi senjang.

3. Material agregat kasar yang digunakan quarry Martadah dengan Awang bangkal.

\section{METODE PENELITIAN}

Perancangan campuran bahan dalam pembuatan benda uji Marshall. Tata cara pembuatan rencana campuran benda uji Marshall yaitu dengan menggunakan Spesifikasi Umum 2010 dan syarat-syarat dalam hasil pengujian. Penentuan proporsi campuran ini berdasarkan batasan nilai spesifikasi gradasi gabungan (Ideal Gradasi) dengan diambilnya nilai tengah dari batasan tersebutlah mendapatkan hasil tertahan saringan. 
Sebuah benda uji memiliki berat campuran 1200 gram. Dari hubungan berat campuran dan hasil tertahan saringan yang telah ditemukan maka kita juga akan mendapatkan hasil persentasi gradasi agregat dan kadar aspal rencana yang merupakan proporsi campuran HRS-Base. Pembuatan benda uji sesuai dengan proporsi yang telah ditentukan. Jumlah pembuatan benda uji adalah 24 buah, yaitu 15 buah untuk pengujian Marshall, 6 buah untuk pengujian Kepadatan Membal (Refusal Density) dan 3 buah untuk pengujian stabilitas Marshall sisa (Perendaman dalam air $60^{\circ} \mathrm{C}$ selama 24 jam).

Tes Marshall adalah untuk mengetahui sifat-sifat campuran aspal, yaitu : Stability, Density, Rongga Udara, Kelelehan (Flow), Koefisien Marshall, Terisi Aspal, Penyerapan Aspal, Kepadatan Membal (Refusal).

Pelaksanaan tes Marshall juga akan memperoleh besarnya beban maksimum yang dapat dipikul oleh benda uji sebelum hancur (Stabilitas Marshall) dan besarnya deformasi dari benda uji sebelum hancur (Kelelehan). Perbandingan stabilitas dan kelelehan merupakan gambaran kekakuan benda uji terhadap deformasi (Marshall Quotient).

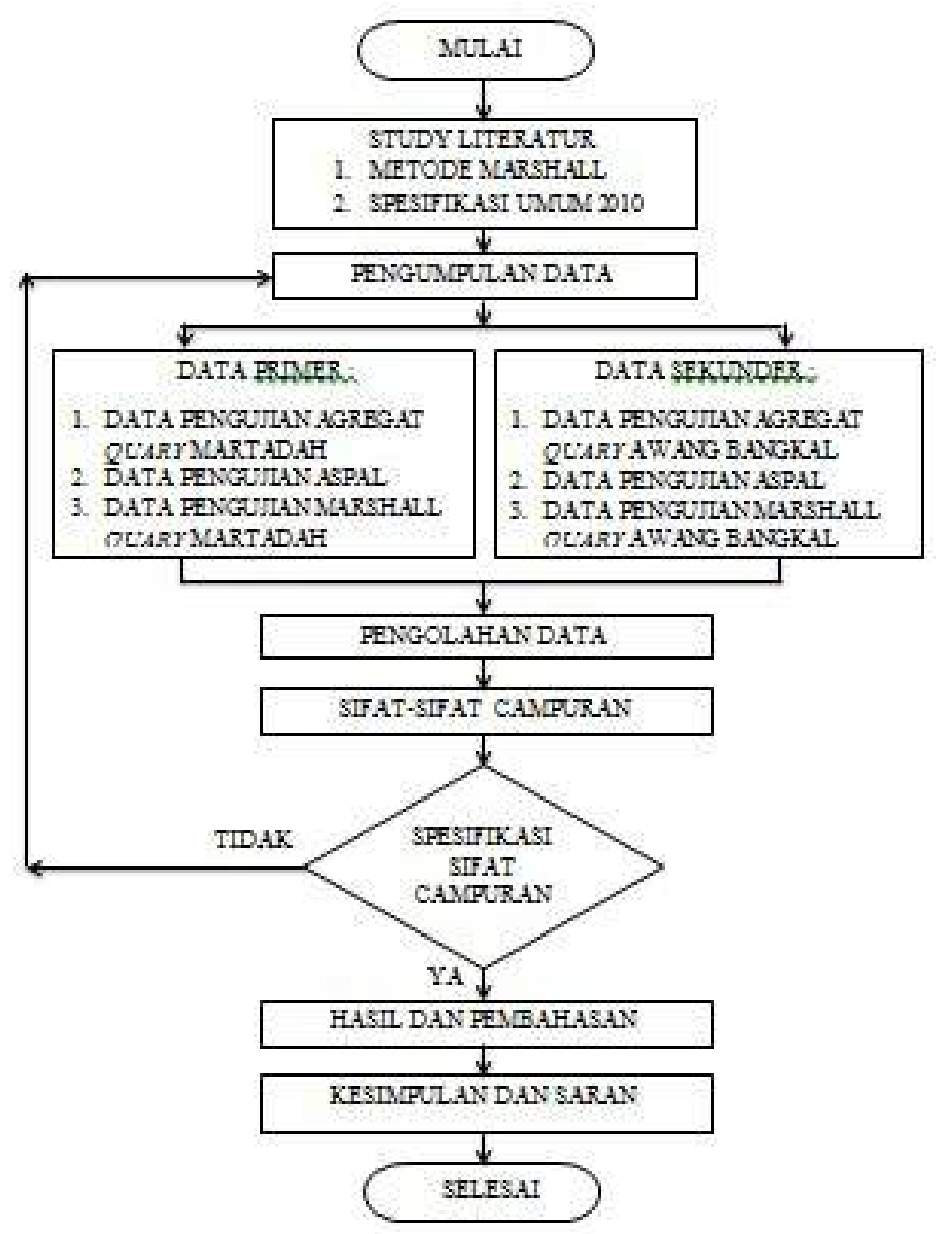

Gambar 1. Bagan Alir Kerangka Penelitian 


\section{HASIL DAN PEMBAHASAN}

Dari pengujian Marshall yang dilaksanakan di laboratorium di dapat sifat-sifat campuran aspal diantaranya VMA, VIM, VFB, Stabilitas, Flow, Marshall Quotient, Kadar Aspal Optimum dan lainnya. Kadar Aspal Optimum pada pengujian Marshall ini adalah 6,55\% untuk quarry Martadah dan 6,40\% yang dihasilkan melalui pengamatan grafik hubungan antar sifat campuran dengan kadar aspal rencana. Hasil data lengkap dapat dilihat pada tabel Marshall Test pada Tabel 1 dan Tabel 2.

Tabel 1. Hasil Sifat Campuran dari Pengujian Marshall quarry Martadah

\begin{tabular}{|c|c|c|c|c|c|c|c|c|c|c|c|c|c|c|c|c|c|c|c|}
\hline $\mathrm{sis}$ & 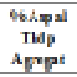 & 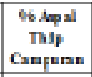 & $\begin{array}{l}\text { Bert } \\
\text { Karrer }\end{array}$ & $\operatorname{sen} x$ & 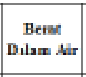 & I내 & Hent is & Bj, Nates & YM. & rM & vrs & $\begin{array}{l}\text { Arsan } \\
\text { Sathas }\end{array}$ & Shailin & 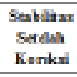 & Kekling & $\begin{array}{l}\text { Ind Bogi } \\
\text { Gartuli }\end{array}$ & 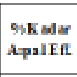 & 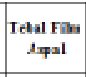 & 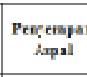 \\
\hline & 16 & s & ar & E & Er & er & & & ts & As & 46 & & 4 & 4. & an & loge & th & & As \\
\hline & $i$ & 1 & $i$ & 1 & $t$ & I & is & 1 & i & $I$ & $\mathbf{k}$ & 1 & i & $I$ & 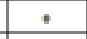 & 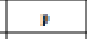 & 4 & $r$ & 5 \\
\hline 18 & & 9,7 & แมย & $n$ & 673 & 529 & 2,237 & 2,4 & 18,81 & 1,36 & 39,19 & $\varphi_{1}, 000$ & 1091,90 & 1041,32 & $\exists, 42$ & 3065 & \multirow{3}{*}{4,34} & \multirow{3}{*}{0,34} & \multirow{3}{*}{ 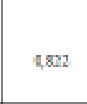 } \\
\hline it & & 5,7 & 1854 & 1285 & 68 & 596 & $2, \mathrm{~W}$ & 2,4 & 19,73 & 3,33 & 52,71 & 6,00 & 765,08 & 714.24 & 3,58 & 202,31 & & & \\
\hline 10. & & 97 & nE & $M$ & 67 & 525 & 2,299 & 2,4 & 1791 & 7,27 & 59,39 & $n, 00$ & $100 /, 90$ & $101: 36$ & 7,95 & 2547 & & & \\
\hline \multicolumn{7}{|c|}{ Dits-min } & 223 & 2,4 & 18,24 & 1,32 & 59,93 & 5,00 & $91,0 \%$ & 925.4 & 3,93 & 1445 & & & \\
\hline $2 \pi$ & & 6,2 & NSSE & 11s & 698 & 518 & 2,2 & 2,8 & 17,24 & 5,35 & 61,59 & $H_{1}, 00$ & 1176,00 & 3174,00 & 4,25 & 276,71 & \multirow{3}{*}{5,35} & \multirow{3}{*}{ B $f$ A } & \multirow{3}{*}{4815} \\
\hline 36 & & 92 & ne & $12 n$ & 677 & 528 & 2,248 & $2, a$ & 18,81 & 7,14 & 62,04 & $T_{0}, 010$ & suen & 84098 & 4,13 & 205,11 & & & \\
\hline $2 \varepsilon$ & & 42 & Has & ith & 61 & 520 & $2: 73$ & 2,4 & 17,24 & is & it,is & $10, \omega$ & 15WHo & 120,0 & 3,4 & sis, 7 & & & \\
\hline \multicolumn{7}{|c|}{ Riv-sil } & $M 7$ & 2,3 & 17,45 & 4,17 & 63,14 & $M, B$ & 1081,00 & 107,3 & 4,05 & MS,81 & & & \\
\hline 30 & & 4,7 & กอบ & 1197 & 61 & 918 & $2, \mathrm{w}$ & $2, n$ & 17,37 & 4,22 & 19,98 & 9,010 & 121,90 & 1121,00 & 4,11 & 274,4 & \multirow{3}{*}{5,83} & \multirow{3}{*}{$\mathrm{B}, \mathrm{as}$} & \multirow{3}{*}{4,813} \\
\hline $3 b$ & & 47 & int & iin & tas & sin & $2: 24$ & $2,2,2$ & 17,51 & 4,4 & "4, In & $1, \omega$ & wit, 00 & $\omega \omega \Delta, \omega$ & 1,37 & w2, & & & \\
\hline a. & & $i 7$ & wit & inh & 61 & 119 & 2811 & 2,4 & $17, \overline{10}$ & 4,14 & 2,77 & $\xi_{1}, \hat{H}$ & $\mid \omega i, \omega$ & $i \xi_{n}, \dot{\omega}$ & 4,18 & $2 \mathrm{H}+4,+1$ & & & \\
\hline \multicolumn{7}{|c|}{ Distan } & 229 & $2, n$ & 17,3 & $4, n 2$ & 4,24 & $n, 67$ & 107,90 & 107,00 & 7,94 & 273,74 & & & \\
\hline 4. & & 72 & 131 & Iith & $6 n$ & 514 & $2 \mathrm{HB}$ & $2, x$ & 17,5 & 1,14 & in, $\Delta$ & $7 t, 0$ & hith & 91605 & $3, k$ & $\mathrm{y}, 7$ & \multirow{3}{*}{439} & \multirow{3}{*}{$\mathrm{N}, 47$} & \multirow{3}{*}{597} \\
\hline $4 b$ & & 72 & Hม! & ital & s4 & sh & 23212 & $1, x$ & $16,4:$ & 24 & $\$ 4,4 ?$ & $n, \dot{\omega}$ & 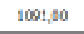 & $i \omega k, \omega$ & $3, \overline{i l}$ & 46,51 & & & \\
\hline 40 & & 72 & Mis & 1117 & $\Leftrightarrow$ & $w 7$ & 2,527 & 2,3 & 1099 & 2,3 & $\$ 4,79$ & 7,000 & $94 \xi, 00$ & 98592 & 3,75 & 24,33 & & & \\
\hline \multicolumn{7}{|c|}{ Bite-nite } & 232 & $2 x$ & 17,14 & 2,15 & $4 \mathrm{H}_{1}, \mathrm{ti}$ & 5:,6? & $w h b$ & ibth, 64 & 1, ne & 23,24 & & & \\
\hline$y_{2}$ & & 7 & Mis & In & $n$ & 311 & 2,200 & 1,7 & 1801 & 2,4 & 99,21 & $n, \infty$ & 720 & 71000 & $3, n$ & $n 1,5$ & \multirow{3}{*}{6,98} & \multirow{3}{*}{17,82} & \multirow{3}{*}{ द2015 } \\
\hline 56 & & 37 & 139 & 116 & 61 & $m$ & 2,311 & $2, \pi T$ & 17,31 & 2,19 & $\mathbf{8 7 , 7 9}$ & $T_{t}+10$ & 3000 & 8985 & $\exists, \pi$ & 242,29 & & & \\
\hline $3 \mathrm{~s}$ & & 7 & Hisi & ain & 为2 & 5 th6 & 2314 & 2,7 & 16,94 & 1,43 & 3,45 & 2,0 & neph & 9104 & 1,4 & $24+34$ & & & \\
\hline \multicolumn{7}{|c|}{ Gitaras } & $13 n$ & 1,77 & $17,3 !$ & 2,6 & 41,15 & $7+\infty$ & $40 \%$ & man & 3,35 & 2423 & & & \\
\hline
\end{tabular}

Tabel 2. Hasil Sifat Campuran dari Pengujian Marshall quarry Awang Bangkal

\begin{tabular}{|c|c|c|c|c|c|c|c|c|c|c|c|c|c|c|c|c|c|c|c|}
\hline So & $\begin{array}{c}\% \text { dipl } \\
\text { Thdp } \\
\text { dgregeat }\end{array}$ & $\begin{array}{l}\text { Watspal } \\
\text { Thdp } \\
\text { Campuran }\end{array}$ & $\begin{array}{l}\text { Bent } \\
\text { Kering }\end{array}$ & Berat SSD & Bent & Isl & 3erat Isl & Bj. $\mathrm{Malks}$ & IXI & ITI & IFB & $\begin{array}{l}\text { Bacaan } \\
\text { Stabilitas }\end{array}$ & Stcbilitas & Sttollitas & Telelehran & $\begin{array}{c}\text { Hasll } \\
\text { Bagi } \\
\text { H grshall } \\
\end{array}$ & $\begin{array}{c}\text { Kadar } \\
\text { tsfalE fif }\end{array}$ & $\begin{array}{l}\text { Tobsl } \\
\text { Film } \\
\text { Aspal }\end{array}$ & $\begin{array}{c}\text { Peп̨уегара } \\
\text { n Aspal }\end{array}$ \\
\hline & है & $\%$ & gI & gr & $\mathrm{gr}$ & & & & & & & & $\mathrm{kg}$ & $\mathrm{kg}$ & $\min$ & $\mathrm{kg} / \mathrm{mm}$ & 㓥 & & 90 \\
\hline & $a$ & b & c & d & e & 1 & $\mathrm{~g}$ & h & 1 & 1 & $\mathbf{k}$ & $\mathrm{I}$ & $\mathrm{ml}$ & $\mathrm{n}$ & 0 & $\mathrm{p}$ & $q$ & r & $s$ \\
\hline $1 \mathrm{I}$ & & $\$ .7$ & $: 18$ & .215 & $5 \pi$ & $5+0$ & 230 & 2.37 & 17,4 & 724 & 58: & 78.00 & 936.10 & 898.46 & 3.80 & $236 .+6$ & & & \\
\hline $\mathbb{b}_{\mathrm{b}}$ & & 5.7 & $: 18$ & .213 & $3 T$ & $5+1$ & 2193 & 237 & 17.49 & 733 & $580^{7}$ & 200 & 861.30 & 861.00 & 300 & 38.00 & -.86 & $5.3 i$ & C.911 \\
\hline ic & & 5.7 & .188 & 211 & 571 & $5+10$ & 2303 & 2.37 & 17,41 & 724 & 58:- & 67.00 & 804.30 & 804.50 & 3.05 & 33.61 & & & \\
\hline \multicolumn{7}{|c|}{ R日I-nitI } & $3 x$ & $\$ 3 i$ & 17.4 & 727 & 58.30 & 733 & 868.50 & 8552 & 3.28 & 32.69 & & & \\
\hline is & & $t_{2}^{2}$ & $\therefore 190$ & .211 & 574 & 536 & $2 \mathrm{mj}$ & $\therefore 3 t$ & 17.09 & 575 & 66.36 & 75.00 & 900.10 & 900.00 & 396 & 276.07 & & & \\
\hline 3 & & $6 ?$ & $: 191$ & 2311 & 572 & $\$ 39$ & 2313 & 3.36 & 17.49 & 620 & $6+56$ & 81.00 & 972.10 & 972.00 & 288 & 337.50 & 1.37 & 113.35 & $c .97$ \\
\hline$x$ & & $6 ?$ & 2190 & 301 & $5 \pi$ & 539 & 2303 & 234 & 1755 & 628 & $6+3$ & 68.00 & 816.10 & 816.50 & t.0! & $33 .+19$ & & & \\
\hline \multicolumn{7}{|c|}{ Rant-nti } & 2.21 & $\pm 3 t$ & 1738 & 6.07 & 65006 & 74.67 & 896.10 & 896.00 & 3.38 & 27215 & & & \\
\hline 3 & & 6.7 & $: 194$ & .200 & $5 T$ & 537 & $2 m$ & .34 & $17,4 !$ & 497 & $7 .+16$ & 68.00 & 816.70 & 816.00 & 3.78 & 28587 & & & \\
\hline 3 & & 6.7 & $: 191$ & .304 & 571 & 533 & 235 & i.34 & 17.00 & +150 & 73.54 & $\pi, 00$ & 98.30 & 98.50 & 350 & 34.00 & 1.87 & 11.37 & 6.90 \\
\hline $3 x$ & & 67 & $: 194$ & .207 & 366 & 539 & 2215 & ¿.34 & 1772 & 532 & 69.97 & 63.00 & 86.10 & 75.76 & 3.80 & 190.99 & & & \\
\hline \multicolumn{7}{|c|}{ Ran-ntI } & 39 & i.3t & 17.38 & 193 & 7.66 & 69.33 & 83.30 & $8: 1 . \%$ & 3.69 & 33.62 & & & \\
\hline 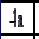 & & 72 & $\therefore 193$ & .203 & 568 & 535 & 273 & i.3i & $17.6 ?$ & 405 & 7700 & $\pi 0.00$ & 840.00 & 806.10 & 3.50 & 30.10 & & & \\
\hline$b$ & & 7.2 & $: 181$ & $: 196$ & $56 x$ & 59 & 233 & 2.3: & 175? & 394 & $775 ?$ & 66.0 & 792.10 & 792.0 & +50 & 176.00 & $6.3^{7}$ & $12+3$ & 6.857 \\
\hline$t 2$ & & 72 & $818 ?$ & .198 & 565 & 536 & 2217 & i.3i & 16.98 & 331 & 80.5 & 62.00 & 741.00 & 74.00 & 3.80 & 19579 & & & \\
\hline \multicolumn{7}{|c|}{ R日n-nIII } & $\therefore 3$ & 2.32 & 1737 & 3.77 & 78.33 & 66.00 & 792.010 & 780.30 & 3.93 & 300.73 & & & \\
\hline 51 & & 77 & $: 188$ & .197 & $56 t$ & 531 & $2 n 3$ & 331 & 18.14 & 350 & 80.72 & 57.00 & 684.50 & 684.00 & +25 & 160.94 & & & \\
\hline$\$$ & & .7 & $: 184$ & $: 195$ & $56 t$ & 530 & 234 & 2.31 & 1791 & 323 & 8.95 & 60.00 & 720.00 & 70.00 & +50 & 160.00 & 6.88 & 13.t7 & C.85? \\
\hline 5 & & 7.7 & $: 181$ & $: 194$ & $56 x$ & 59 & 233 & ¿.31 & 1790 & 330 & $8: 66$ & 51.00 & 612.50 & 612.00 & +.39 & $139 .+1$ & & & \\
\hline \multicolumn{7}{|c|}{ Ratt-IItI } & $2 n$ & i..31 & 18.00 & 334 & 8..H & 56.00 & 67.30 & 672.0 & 4.38 & $153 .+5$ & & & \\
\hline
\end{tabular}


Setelah pengujian pada 15 buah benda uji dalam pengujian Marshall, maka didapatkan hasil Kadar Aspal Optimum. Pada hasil yang ditelah diamati maka didapatkan hasil Kadar Aspal Optimum (KAO) campuran, yaitu adalah 6,55\% untuk quarry Martadah dan $6.40 \%$ untuk quarry Awang Bangkal. Dengan adanya hasil kadar aspal optimum yang ada dilanjutkan dengan pembuatan 9 buah benda uji kembali, yaitu 6 buah benda uji untuk pengujian Kepadatan Mutlak (Refusal) dan 3 buah benda uji untuk Stabilitas Sisa Marshall (Perendaman dalam air waktu 24 jam, $\left.60^{\circ} \mathrm{C}\right)$.

Pada pembuatan benda uji ini pada dasarnya sama saja dengan standar pembuatan benda uji untuk pengujian Marshall hanya saja ada perbedaan jumlah tumbukan untuk pemadatan pada benda uji untuk pengujian Kepadatan Mutlak yaitu 400 kali tumbukan per bidang benda uji. Hasilnya seperti berikut pada Tabel 3 dan Tabel 4.

Tabel 3. Hasil Pengujian Kepadatan Mutlak (Refusal) - quarry Martadah

\begin{tabular}{|c|c|c|c|c|c|c|c|c|}
\hline No & $\begin{array}{l}\% \text { Aspal } \\
\text { Thdp } \\
\text { Camporan }\end{array}$ & $\begin{array}{c}\text { Berat } \\
\text { Kering }\end{array}$ & Beral SSD & $\begin{array}{c}\text { Berar } \\
\text { Dall am Air }\end{array}$ & Isi & Berat I si & Bj- Mraks & VTXI \\
\hline & 90 & $\approx r$ & ser & *r & $x$ & & & 36 \\
\hline $1 \mathbf{a}$ & 0,05 & 1180 & 1193 & 670 & 517 & 2,282 & $2=424$ & 5,846 \\
\hline $1 b$ & 0.03 & 1181 & 1194 & 677 & 517 & 2,284 & 2.424 & 5.760 \\
\hline \multicolumn{6}{|c|}{ Ridid-Tidide } & 2,283 & 2.424 & 5.800 \\
\hline 2iat & 0,55 & 1187 & 1193 & 079 & 514 & 2,309 & 2,407 & 4,055 \\
\hline 26 & $6=55$ & 1186 & 1191 & 677 & 514 & 2,307 & $2=407$ & $4=136$ \\
\hline \multicolumn{6}{|c|}{ Rata-rata } & 2,908 & 2.407 & 4.096 \\
\hline $3 a$ & 7.05 & 1170 & 1185 & 677 & 508 & $2,3: 21$ & 2,300 & $2,80.1$ \\
\hline $3 \mathrm{~b}$ & 7.05 & 1178 & 1183 & 675 & 508 & 2,319 & 2.390 & 2.976 \\
\hline \multicolumn{6}{|c|}{ Rata-rata } & 2,320 & 2,390 & 2,935 \\
\hline
\end{tabular}

Tabel 4. Hasil Pengujian Kepadatan Mutlak (Refusal) - quarry Awang Bangkal

\begin{tabular}{|c|c|c|c|c|c|c|c|c|c|}
\hline \multirow[t]{2}{*}{ No } & $\begin{array}{l}\% \text { Aspal } \\
\text { I hdp } \\
\text { Agre rat }\end{array}$ & $\begin{array}{l}\% \text { Aspal } \\
1 \text { hdp } \\
\text { C ampuran }\end{array}$ & $\begin{array}{c}\text { Be rat } \\
\text { Ke ring }\end{array}$ & Berat SSU & $\begin{array}{c}\text { Be rat } \\
\text { Dalam Air }\end{array}$ & Isi & Berat Isi & Bj. Mlaks & VL1 \\
\hline & $\%$ & $\begin{array}{l}\% \\
\text { b }\end{array}$ & $\begin{array}{l}\mathrm{gr} \\
\mathrm{e}\end{array}$ & $\begin{array}{l}\mathrm{gr} \\
\mathrm{d}\end{array}$ & $\begin{array}{l}\mathrm{yr} \\
\mathrm{e}\end{array}$ & $f$ & $=$ & h & $\mathbf{j}$ \\
\hline la & & 5.9 & 1190 & 1229 & 700 & 529 & 2.250 & 2.37 & 4.92 \\
\hline $1 b$ & & 5.9 & 1187 & 1228 & 702 & 526 & 2.257 & 2.37 & 4.62 \\
\hline \multicolumn{7}{|c|}{ Rate-rata } & 2.25 & 2.37 & 4.77 \\
\hline $2 a$ & & 6.4 & 1188 & 1230 & 701 & 529 & 2.246 & 2.35 & 4.43 \\
\hline $2 \mathrm{~b}$ & & 6.4 & 1191 & 1232 & 700 & 532 & 2.239 & 2.35 & 4.73 \\
\hline \multicolumn{7}{|c|}{ Kata-rata } & 2.24 & 2.35 & 4.58 \\
\hline $3 a$ & & 6.9 & 1187 & 1236 & 703 & 533 & 2.227 & 2.33 & 4.59 \\
\hline $3 b$ & & 6.9 & 1188 & 1237 & 704 & 533 & 2.229 & 2.33 & 4.51 \\
\hline \multicolumn{7}{|c|}{ Rata-rata } & 2.23 & 2.33 & 4.55 \\
\hline
\end{tabular}

Selain melaksanakan pengujian Kepadatan Mutlak untuk mendapatkan Void In Mix at Percentage Refusal Density (VIM at PRD), adapula pengujian untuk mendapatkan persentasi Stabilitas Marshall sisa, yaitu dengan pelaksanaan pengujian Marshall dengan perendaman benda uji kedalam air suhu $60^{\circ} \mathrm{C}$ selama waktu 24 jam. Pada pembuatan ini pada dasarnya sama dengan standar pembuatan benda uji untuk pengujian Marshall. Dengan mendapatkannya hasil stabilitas pada perendaman maka dapat dibandingan persentasi dengan stabilitas pada pengujian Marshall. Maka hasil tersebutlah yang merupakan persentasi Stabilitas Marshall Sisa. Hasil pengujian Stabilitas Marshall sisa dapat dilihat pada Tabel 5 dan Tabel 6.

Tabel 5. Hasil Pengujian Stabilitas Marshall dengan Perendaman Dalam Air Suhu $6^{\circ} \mathrm{C}$ dalam Waktu 24 Jam (Martadah)

\begin{tabular}{|c|c|c|c|}
\hline \multirow[t]{2}{*}{ No } & $\begin{array}{c}\text { \% Aspal } \\
\text { Thdp } \\
\text { Campuran }\end{array}$ & $\begin{array}{c}\text { Bacaan } \\
\text { Stabilitas }\end{array}$ & $\begin{array}{c}\text { Stabilitas } \\
\text { Sete lah } \\
\text { Kore ks i } \\
\end{array}$ \\
\hline & $\%$ & & $\mathbf{k g}$ \\
\hline & $\mathbf{b}$ & $\mathbf{e}$ & $\mathbf{e}$ \\
\hline R1 & 6.55 & 88.00 & 1013.76 \\
\hline $\mathbf{R 2}$ & 6.55 & 84.00 & 937.44 \\
\hline $\mathbf{R 3}$ & 6.55 & 85.00 & 979.20 \\
\hline \multicolumn{2}{|c|}{ Rata-rata } & 85.67 & 976.80 \\
\hline
\end{tabular}


Stabilitas Pengujian Marshall

Stabilitas Marshall Sisa

$=1083,41 \mathrm{~kg}$

$=976,80 \mathrm{~kg}$

$=976,80 / 1083,41 \times 100 \%=90,159 \%$

Tabel 6. Hasil Pengujian Stabilitas Marshall dengan Perendaman Dalam Air Suhu $60^{\circ} \mathrm{C}$ dalam Waktu 24 Jam (Awang Bangkal) Tabel 7 :

\begin{tabular}{|c|c|c|c|}
\hline \multirow{2}{*}{ so } & $\begin{array}{c}\text { \% Aspal } \\
\text { Thdp } \\
\text { Campuran }\end{array}$ & $\begin{array}{c}\text { Bacaan } \\
\text { Stabilitas }\end{array}$ & $\begin{array}{c}\text { Stabilitas } \\
\text { Sete lah } \\
\text { Kore ksi }\end{array}$ \\
\cline { 2 - 4 } & \% & & kg \\
\hline & b & c & e \\
\hline R1 & 6.4 & 70.00 & 806.40 \\
\hline R2 & 6.4 & 67.00 & 747.72 \\
\hline R3 & 6.4 & 69.00 & 794.88 \\
\hline \multicolumn{2}{|c|}{ Rata-rata } & 68.67 & 783.00 \\
\hline
\end{tabular}

Stabilitas Pengujian Marshall $\quad=865,30 \mathrm{~kg}$

Stabilitas Marshall Sisa $\quad=783,00 \mathrm{~kg}$

Persentasi Stabilitas Marshall Sisa $\quad=783,00 / 865,30 \times 100 \%=90,489 \%$

Data hasil perhitungan dari pengujian Marshall yang telah dilaksanakan dapat dilihat pada

Tabel 7. Sifat-sifat Campuran Aspal Lataston HRS-Base Hasil Pengujian Marshall (Kadar Aspal Optimum 6,55\% dan 6,40\%)

\begin{tabular}{|c|c|c|c|c|}
\hline \multirow{3}{*}{ Sifat sifat Campuran } & & \multicolumn{3}{|c|}{$\begin{array}{l}\text { Lat3sion } \\
\text { 1.spis Postasi }\end{array}$} \\
\hline & & \multicolumn{2}{|c|}{ Hasii } & \multirow[b]{2}{*}{ Spesifikssi } \\
\hline & & Marradah & $\begin{array}{c}\text { Aw. } \\
\text { Bungkud }\end{array}$ & \\
\hline Katar Argelefand (x) & Wha. & 5.74 & 557 & 5.5 \\
\hline Peryermon Aapd $(Y)$ & Bage. & 0.315 & 0905 & 1.7 \\
\hline \multirow{2}{*}{ Ronger dism Cmpuren (VIMD) } & Wal. & \multirow{2}{*}{4.89} & \multirow{2}{*}{$\$ .51$} & 4 \\
\hline & Bager. & & & 6 \\
\hline 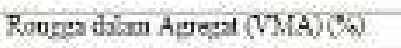 & Win. & 1736 & 1728 & 17 \\
\hline Ponige Titio Axyd ( $\%)$ & Mar. & 7232 & 63.20 & 65 \\
\hline Stabdrta LAashall (kg) & Mat. & 163541 & 865.20 & 800 \\
\hline Pegeran ( $\mathrm{mm})$ & Wal. & 4.05 & 2.49 & 3 \\
\hline 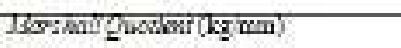 & Ma. & $2 \pi .50$ & 250.25 & 250 \\
\hline 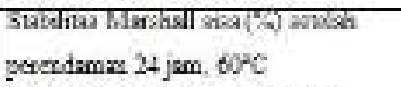 & Wha. & 90.159 & 96.42 & 90 \\
\hline 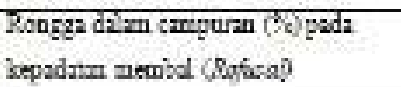 & Man. & 4.10 & 4.60 & 3 \\
\hline
\end{tabular}

Dari hasil data tersebut adalah hasil pelaksanaan pembuatan benda uji Marshall dengan agregat quarry Martadah dan quarry Awang Bangkal yang dasarnya dirancang dengan menggunakan Spesifikasi Umum 2010 yang telah dijelaskan.. Sifat-sifat campuran Lataston hasil perhitungan Marshall ini secara keseluruhan telah memenuhi spesifikasi yang telah ditentukan. Dibawah ini merupakan diagram-diagram perbandingan nilai sifat-sifat campuran Lataston pada kedua agregat yang telah diuji. 


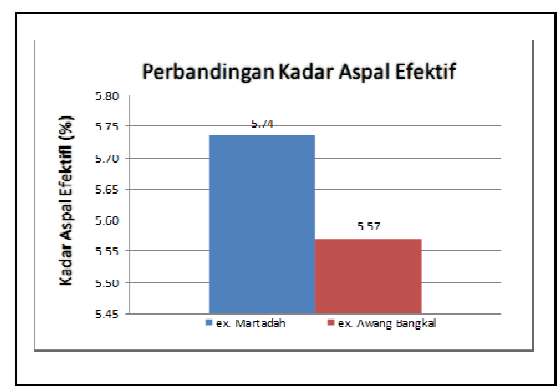

Gambar 2. Diagram Perbandingan Kadar Aspal Efektif

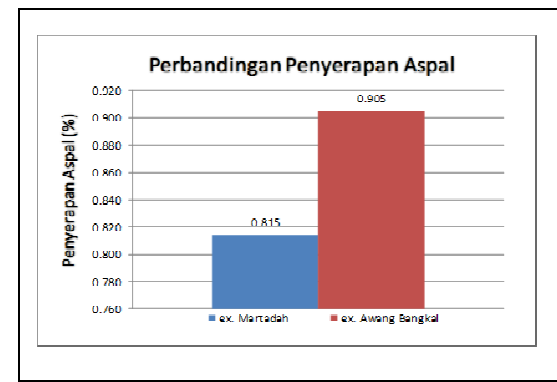

Gambar 3. Diagram Perbandingan Penyerapan Aspal

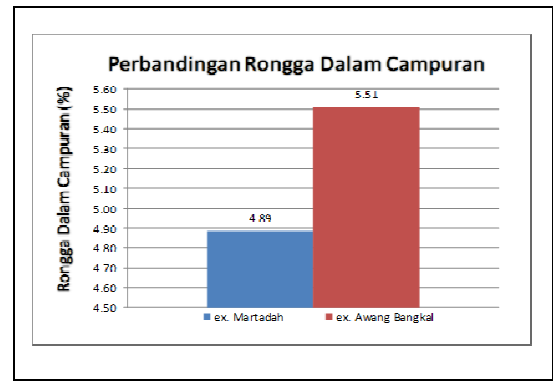

Gambar 4. Diagram Perbandingan Rongga Dalam Campuran

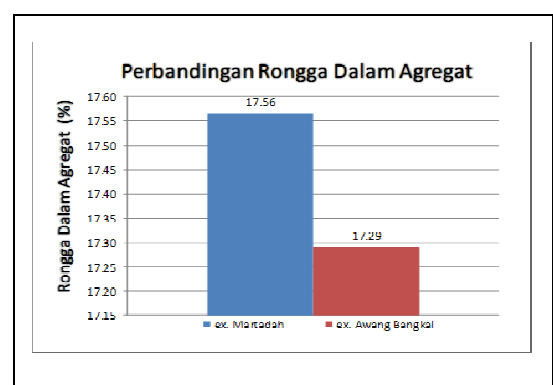

Gambar 5. Diagram Perbandingan Rongga Dalam Agregat

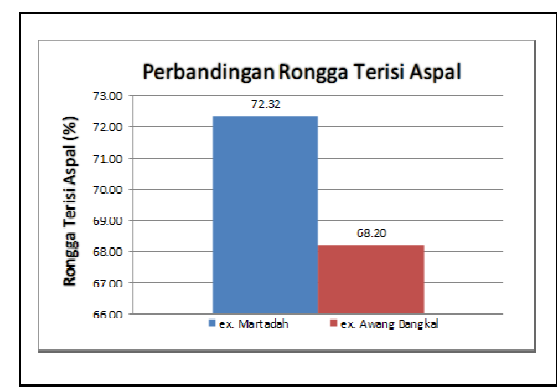

Gambar 6. Diagram Perbandingan Rongga Terisi Aspal 


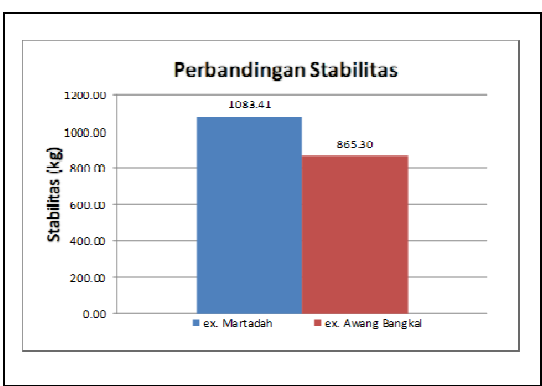

Gambar 7. Diagram Perbandingan Stabilitas

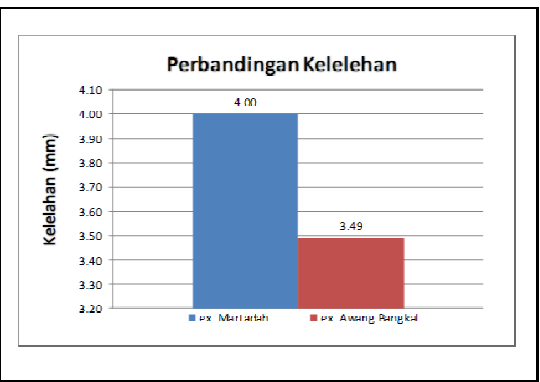

Gambar 8. Diagram Perbandingan Kelelehan

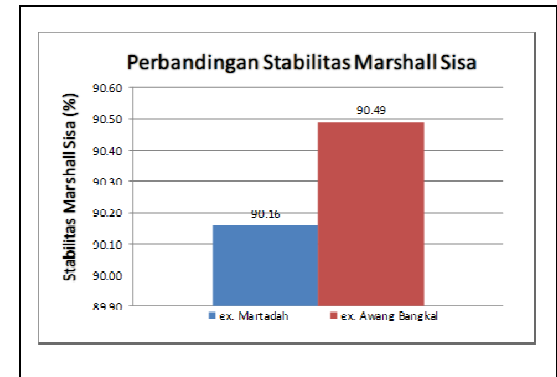

Gambar 9. Diagram Perbandingan Stabilitas Marshall Sisa

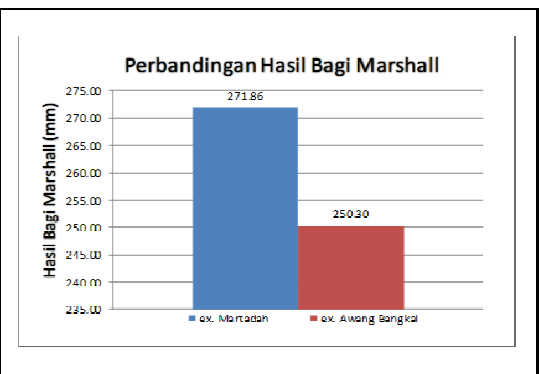

Gambar 10. Diagram Perbandingan Hasil Bagi Marshall

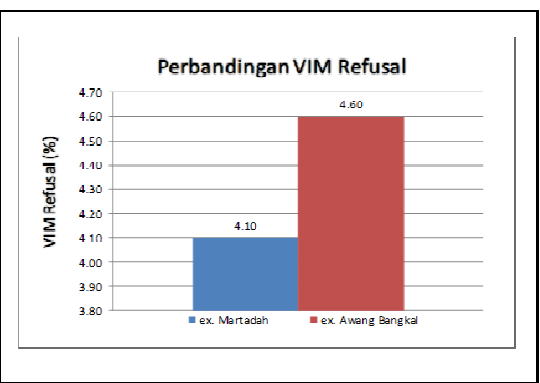

Gambar 11. Diagram Perbandingan VIM Refusal 


\section{KESIMPULAN DAN}

\section{SARAN Kesimpulan}

1. Dari hasil pengujian Marshall yang telah dilakukan maka kita mendapatkan nilai sifat-sifat campuran yang dimiliki Lataston HRS-Base Gradasi Senjang dengan menggunakan agregat kasar quarry Martadah, sebagai berikut:

\section{Tabel 8. Sifat-sifat Campuran Aspal Lataston HRS-Base Hasil Pengujian Marshall} dengan agregat quarry Martadah

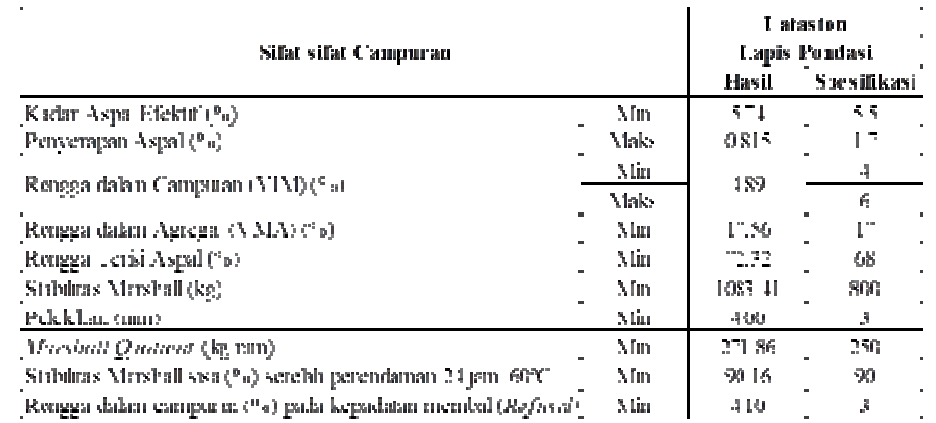

2. Dari hasil pengujian Marshall yang telah dilakukan maka kita mendapatkan nilai sifat-sifat campuran yang dimiliki Lataston HRS-Base Gradasi Senjang dengan menggunakan agregat kasar quarry Awang Bangkal, sebagai berikut:

Tabel 9. Sifat-sifat Campuran Aspal Lataston HRS-Base Hasil Pengujian Marshall dengan agregat quarry Awang Bangkal

\begin{tabular}{|c|c|c|c|}
\hline \multirow{2}{*}{ 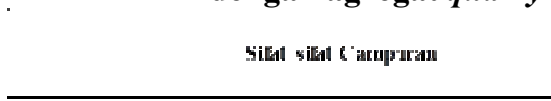 } & \multirow{2}{*}{ 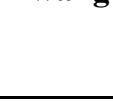 } & \multicolumn{2}{|c|}{ 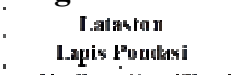 } \\
\hline & & Husil & Sprsilih asi \\
\hline 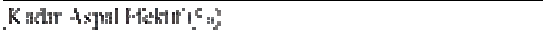 & yn: & $\approx-$ & $\overline{5}$ \\
\hline 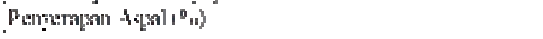 & Maks & $0 \mathrm{mi}$ & $1^{-}$ \\
\hline R congha dahan ( & Min:. & $\approx$ & + \\
\hline 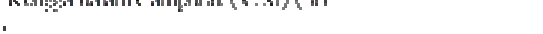 & Maks & a & \\
\hline 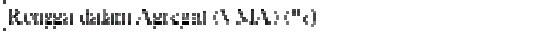 & . Su. & L".."3 & ]"- \\
\hline "Kutugy - - & . Mul.. & 48.0 & $\mathrm{Gs}$ \\
\hline 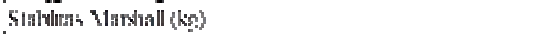 & Mn: & $\mathrm{K}: 90$ & $\sin$ \\
\hline 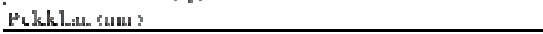 & يل. & $7 .+y$ & 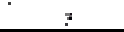 \\
\hline 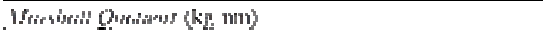 & yn: & 70190 & 90 \\
\hline 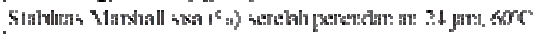 & צn: & $x: 5$ & 90 \\
\hline 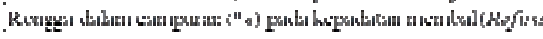 & Sin:. & +. & $=$ \\
\hline
\end{tabular}

3. Dari hasil/ nilai pada pengujian Marshall pada kedua agregat maka dapat kita simpulkan bahwa secara garis besar nilai sifat-sifat campuran pada Lataston quarry Martadah lebih besar dibandingkan dengan quarry Awang Bangkal. Hal tersebut dapat kita lihat pada Tabel 10 bahwa 6 dari 10 nilai sifat campuran yang dimiliki Lataston quarry Martadah lebih tinggi daripada Lataston quarry Awang Bangkal.

Tabel 10. Perbandingan Nilai Sifat-sifat Campuran Aspal Lataston HRS-Base

\begin{tabular}{|c|c|c|}
\hline \multirow[t]{2}{*}{ Si fat sifat C :ampuran } & \multicolumn{2}{|c|}{$\begin{array}{l}\text { I.allis ton } \\
\text { 1.api Pandasi } \\
\text { VilaiHanil }\end{array}$} \\
\hline & Hatotulalı & $A n_{1} B$ alugk ill \\
\hline 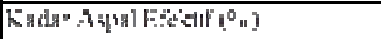 & 7 & 5 \\
\hline 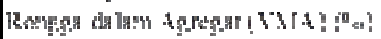 & 178 & $1: 29$ \\
\hline 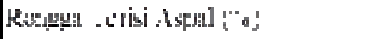 & :ב...ב & 68 \\
\hline 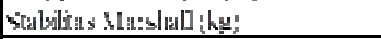 & ]0k:-4L & 8640 \\
\hline 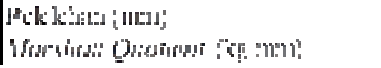 & $\begin{array}{l}400 \\
n 186\end{array}$ & $\begin{array}{l}1.45 \\
5010\end{array}$ \\
\hline
\end{tabular}

\section{Saran}

1. Perlunya ketelitian dan kecermatan selama pelaksanaan penelitian terutama pada saat penimbangan, pengontrolan temperatur saat pencampuran dan pemadatan sehingga hasil yang diperoleh dapat optimal.

2. Seluruh perhitungan sangatlah bersifat sensitif akan ketelitian, sehingga penghitungan harus sangat diperhatikan ketelitian. 


\section{REFERENSI.}

Buku 1 Penulis

Sigit, Hari Pradityo. Pengertian Lapis Tipis Aspal Beton (Lataston). Polinema.

\section{Penulis Dengan Beberapa Buku}

Sukirman, Silvia. 2003. Beton Aspal Campuran Panas. Granit. Bandung.

Sukirman, Silvia. 1992. Perkerasan Lentur Jalan Raya. Nova. Bandung.

Tabel 10 Perbandingan Nilai Sifat-sifat Campuran Aspal Lataston HRSBase

Penulis Tidak Diketahui / Lembaga

Universitas Islam Kalimantan. 2018. Panduan Penulisan Proposal Skripsi Jurusan Teknik Sipil Edisi Update. UNISKA Banjarmasin. Banjarmasin.

\section{Artikel Jurnal 1 Penulis}

Akem. 2012. Jurnal Teknik Sipil Untan / Volume 12 Nomor 2 (Pengaruh Suhu Pemadatan pada Lapis Perkerasan Lataston). Teknik Sipil Fakultas Teknik Universitas Tanjungpura. Tanjungpura.

\section{Artikel Jurnal 2 Penulis}

A Syaifullah dan Wisafri. 2002. Jurnal R \& B Volume 2 Nomor (Kinerja Laboratorium Dari Lapis Tipis Aspal Beton). Teknik Sipil Politeknik Negeri Padang. Padang.

\section{Artikel Jurnal Laboratorium}

Mamangkey, Rizky. 2013. Jurnal Sipil Statik Volume 1 Nomor 3 (Kajian Laboratorium Sifat Fisik Agregat Yang Mempengaruhi Nilai VMA Pada Campuran Beraspal Panas HRS-WC). Teknik Sipil Universitas Sam Ratulangi.

\section{Spesifikasi Campuran Lataston}

Spesifikasi Umum 2010. Spesifikasi Ketentuan Sifat-Sifat Campuran Lataston.

Spesifikasi Pengujian Analisa Saringan Agregat

SNI 03-1968-1990. Metode Pengujian Analisa Saringan Gradasi Agregat.

\section{Spesifikasi Pengujian Berat Aspal}

SNI 06-2441-1991. Metode Pengujian Berat Aspal Padat.

\section{Spesifikasi Pengujian Berat Jenis dan Penyerapan Agregat}

SNI 03-1970-1990. Metode Pengujian Berat Jenis dan Penyerapan Agregat.

\section{Spesifikasi Pengujian Daktilitas Aspal}

SNI 06-2432-1991. Metode Pengujian Daktilitas Bahan-Bahan Aspal.

Spesifikasi Pengujian Keausan Agregat dengan Mesin Los Angeles

SNI 03-2417-1991. Metode Pengujian Keausan Agregat dengan Abrasi Mesin Los Angeles.

\section{Spesifikasi Pengujian Penterasi Bitumen}

SNI 06-2456-1991. Metode Pengujian Penetrasi Bahan-Bahan Bitumen.

\section{Spesifikasi Pengujian Titik Lembek Aspal}

SNI 06-2434-1991. Metode Pengujian Titik Lembek Aspal dan Ter. 